\title{
ANGKA HARAPAN HIDUP DI ERA DESENTRALISASI (KABUPATEN/KOTA JAWA BARAT)
}

\author{
Adhitya Wardhana ${ }^{1}$ \\ Bayu Kharisma ${ }^{2}$ \\ Fakultas Ekonomi dan Bisnis Universitas Padjadjaran, Jawa Barat, Indonesia ${ }^{1,2}$ \\ Email :adhitya.wardhana@fe.unpad.ac.id
}

\begin{abstract}
This study aims to explains the development of life expectancy (AHH) in West Java Regency/City. Variable of life expectancy in this study is influenced by income (GRDP), access to clean water, mean of years schooling and poverty. The scope of the study was separated into two regional classifications in West Java that were in a condition of life expectancy under the age of 71 and 72 years. The research method used is the panel data method and The Generalized Least Square $(G L S)$ model. The results of this study explain the variable income (GRDP), access to clean water and mean of years schooling have a positive and significant effect on AHH under the age of 71 years. Meanwhile, the independent variables that have a positive and significant influence on life expectancy below 72 years are income $(G R D P)$ and poverty. Income variable (GRDP) becomes an independent variable that affects $A H H$ at age 71 and 72 years.
\end{abstract}

Keywords: AHH; income (GRDP); access to clean water; mean of years schooling; Generalized Least Square (GLS).

\begin{abstract}
ABSTRAK
Penelitian ini menjelaskan perkembangan angka harapan hidup (AHH) di Kabupaten/Kota Jawa Barat. Variabel angka harapan hidup dalam penelitian ini dipengaruhi oleh pendapatan (PDRB), akses air bersih, rata-rata lama sekolah dan kemiskinan. Ruang lingkup penelitian dipisahkan menjadi dua klasifikasi daerah di Jawa Barat yang berada pada kondisi angka harapan hidup dibawah usia 71 dan 72 tahun. Metode penelitian yang digunakan yaitu metode panel data dan menggunakan model Generalized Least Square (GLS). Hasil penelitian ini menjelaskan variabel pendapatan (PDRB), akses air bersih dan rata-rata lama sekolah mempengaruhi positif dan signifikan terhadap AHH dibawah usia 71 tahun. Sementara itu, variabel bebas yang mempengaruhi positif dan signifikan terhadap angka harapan hidup dibawah usia 72 tahun adalah variabel pendapatan (PDRB) dan kemiskinan. Variabel pendapatan (PDRB) menjadi variabel independ yang mempengaruhi AHH di usia 71 dan 72 tahun.
\end{abstract}

Kata Kunci : AHH; pendapatan (PDRB); akses air bersih; rata-rata lama sekolah; Generalized Least Square (GLS). 


\section{PENDAHULUAN}

Sektor kesehatan adalah salah satu sektor prioritas yang dapat mempengaruhi kehidupan masyarakat dan pembangunan bidang kesehatan, dimana peningkatan sektor kesehatan dapat melalui peningkatan pelayanan kesehatan perorangan dan pelayanan kesehatan masyarakat. Pembangunan kesehatan merupakan sasaran dalam meningkatkan kualitas SDM. Dalam hal ini, pembangunan kesehatan mengarah terhadap kesadaran masyarakat dan keinginan masyarakat untuk hidup sehat. Peningkatan derajat kesehatan diwujudkan untuk mencapai kesehatan masyarakat setinggi-tingginya.

Salah satu indikator keberhasilan pembangunan dapat melihat perkembangan angka harapan hidup suatu daerah $(\mathrm{AHH})$. Angka harapan hidup merupakan standar suatu negara maupun daerah untuk mengukur keberhasilan pemerintah dalam meningkatkan kesehatan masyarakat. Upaya pemerintah melalui dukungan maksimal terhadap kesehatan masyarakat dapat dilihat dari perkembangan angka harapan hidup. Angka harapan hidup merupakan cerminan kualitas hidup masyarakat dan kualitas kesehatan suatu daerah. Perkembangan yang positif dari angka harapan hidup menjadi cerminan target dari kebijakan kesehatan. Peningkatan angka harapan hidup harus dibarengi oleh indikator kesehatan maupun indikator pendidikan.

Menurut Khan \& Raza (2016), bahwa harapan hidup saat lahir sebagai indikator kesehatan yang bermanfaat dan secara luas sebagai indikator umum pembangunan nasional. Indikator umur panjang sebagai salah satu fungsi utama untuk pembangunan ekonomi. Harapan hidup dapat dipengaruhi oleh pendapatan, 
pendidikan, kesehatan dan nutrisi. Tingkat pendapatan yang tinggi diperlukan untuk memastikan tingkat harapan hidup yang tinggi. Namun, ini bukan kondisi yang memadai untuk memastikan tingkat harapan hidup yang diinginkan.

Provinsi Jawa Barat merupakan salah satu provinsi dengan populasi terbanyak di Indonesia, selain Provinsi DKI, Jawa Tengah dan Jawa Timur. Penduduk provinsi Jawa Barat yang tinggi menjadi harus dibarengi dengan kesehatan penduduk yang dapat dilihat dari perkembangan AHH di Jawa Barat. Perkembangan AHH di Jawa Barat dalam setiap tahunnya mengalami peningkatan.

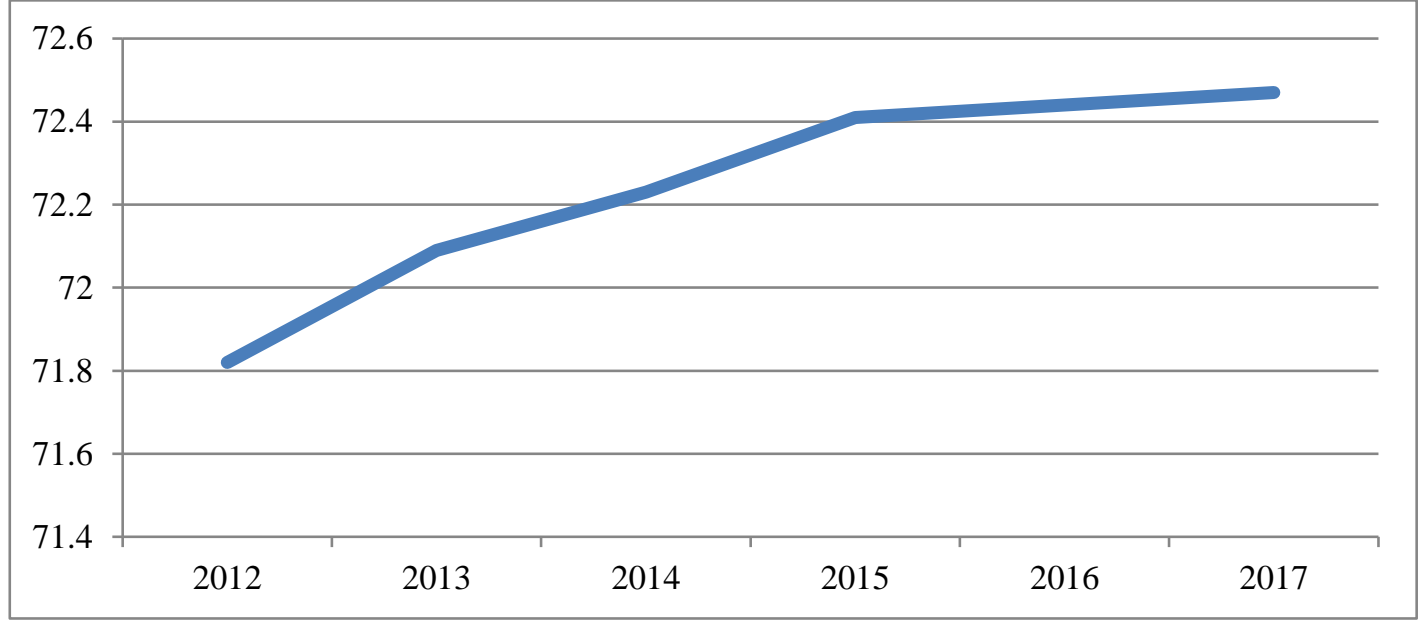

Sumber : BPS Jawa Barat

\section{Grafik 1. Angka Harapan Hidup Provinsi Jawa Barat Tahun 2012-2017 (umur)}

Terlihat pada Grafik 1 menunjukkan bahwa nilai AHH provinsi mengalami kenaikan, nilai rata-rata AHH Provinsi Jawa Barat sebesar 74.24 pada tahun 20122017. Perkembangan AHH Provinsi Jawa Barat relatif stabil setiap tahunnya, hal ini perlunya upaya yang lebih besar dalam meningkatkan AHH Provinsi Jawa Barat. Sasaran dan target RPMJD Provinsi Jawa Barat tahun 2018-2023 untuk 
Indikator AHH pada kisaran 71-72 tahun. Angka Harapan Hidup Provinsi Jawa Barat sudah mencapai sasaran RPJMD Provinsi Jawa Barat tahun 2013-2023.

Perkembangan AHH yang kian meningkat di Provinsi Jawa Barat diharapkan dapat diikuti oleh Kabupaten/Kota di Jawa Barat. Pada Grafik 2 memperlihatkan kabupaten/Kota Jawa Barat yang sudah mencapai umur antara 71-72 tahun, dimana hanya delapan daerah yang sudah melebihi target $\mathrm{AHH}$ untuk 72 tahun. Kabupaten/kota yang sudah melebihi AHH 72 tahun yaitu Kab. Bandung, Kab. Bekasi, Kab. Kuningan, Kota Bandung, Kota Bekasi, Kota Bogor, Kota Cimahi dan Kota Depok, sedangkan daerah yang sudah melebihi target AHH 71 tahun diantaranya : Kab. Bandung Barat, Kabupaten Ciamis, Kab. Cirebon, Kab. Karawang, Kab. Subang, Kab. Sumedang, Kota Cirebon, Kota Sukabumi dan Kota Tasikmalaya.

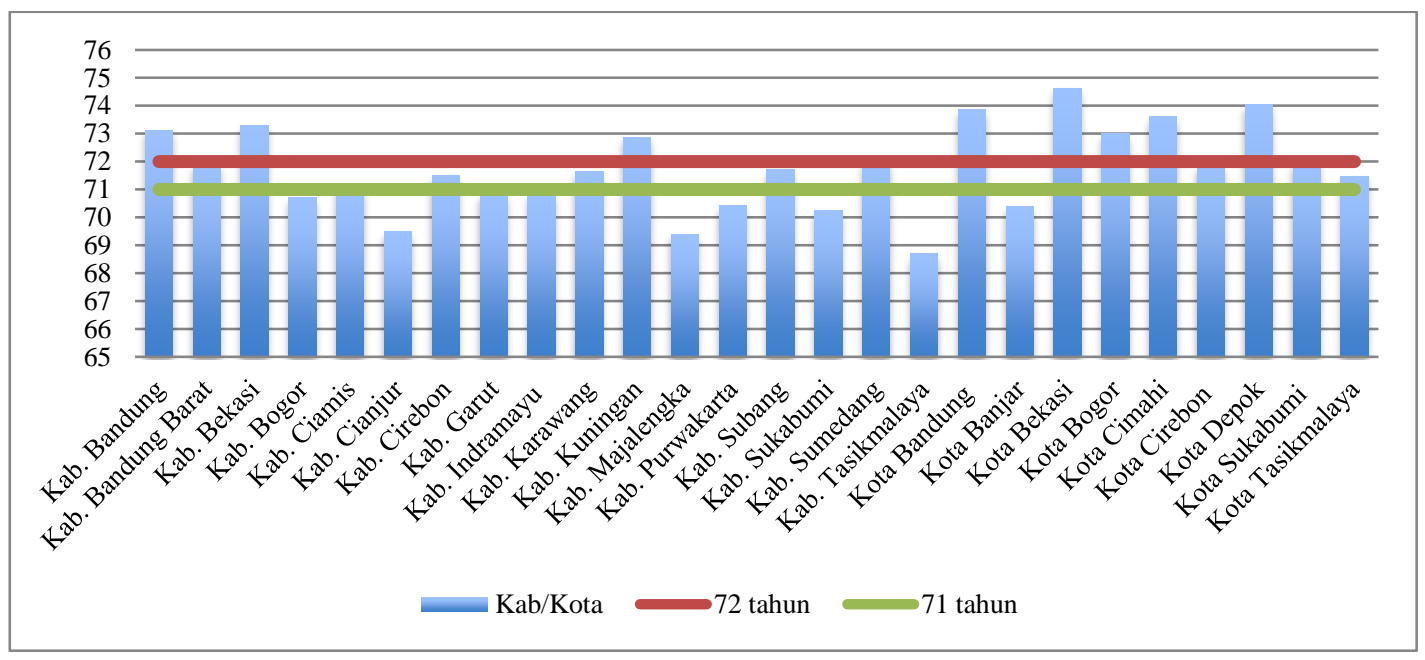

Sumber: BPS, data diolah.

\section{Grafik 2.}

\section{Angka Harapan Hidup Kabupaten/Kota Provinsi Jawa Barat Tahun 2017}

Selanjutnya, beberapa daerah di Jawa Barat yang memiliki AHH dibawah 71 tahun yaitu Kab. Bogor, Kab. Cianjur, Kab. Garut, Kab. Indramayu, Kab. 
Majalengka, Kab. Purwakarta, Kab. Sukabumi, Kab. Tasikmalaya dan Kota Banjar. Sembilan Kabupaten/Kota di Jawa Barat masih berada dibawah AHH 71 tahun. Berdasarkan Grafik 2, masih banyak AHH Kabupaten/Kota di Jawa Barat yang berada dibawah 71 tahun, berikut tabel Kabupaten/Kota Jawa Barat yang dibawah 71 tahun, diatas 71 tahun dan diatas 72 tahun.

Tabel 1 memperlihatkan profil ragam kesehatan pada angka harapan hidup di Kabupaten/Kota Jawa Barat. Setiap daerah berusaha untuk meningkatkan kesehatan masyarakat melalui outcome angka harapan hidup. Hanya sedikit Kabupaten/Kota yang sudah melebihi target AHH 72 tahun, sedangkan kabupaten/kota Jawa Barat lainnya mayoritas masih dibawah AHH 71 tahun. Berdasarkan hal tersebut, kepedulian terhadap kesehatan masih relatif rendah. Alokasi belanja kesehatan menjadi prioritas dalam meningkatkan kesehatan masyarakat. Di era desentralisasi fiskal seharusnya pemerintah daerah lebih leluasa dalam mengalokasi belanjanya untuk kesehatan.

Tabel 1.

\section{Kelompok Angka Harapan Hidup Kabupaten/Kota di Jawa Barat Tahun 2017}

\begin{tabular}{llrl}
\hline $\begin{array}{l}\text { Kabupaten/Kota } \\
\text { dibawah AHH (71 tahun) }\end{array}$ & $\begin{array}{l}\text { Kabupaten/Kota diatas } \\
\text { AHH (71 Tahun) }\end{array}$ & $\begin{array}{l}\text { Kabupaten/Kota diatas } \\
\text { AHH (72 Tahun) }\end{array}$ \\
\hline Kab. Bogor, Kab. Cianjur, & Kab. Bandung $\quad$ Barat, & Kab. Bandung, Kab. Bekasi, \\
Kab. Garut, Kab. Indramayu, & Kabupaten Ciamis, Kab. & $\begin{array}{l}\text { Kab. Kuningan, Kota } \\
\text { Kab. Majalengka, Kab. }\end{array}$ & $\begin{array}{l}\text { Cirebon, Kab. Karawang, } \\
\text { Bandung, Kota Bekasi, Kota }\end{array}$ \\
$\begin{array}{l}\text { Purwakarta, Kab. Sukabumi, } \\
\text { Kab. Tasikmalaya dan Kota } \\
\text { Banjar }\end{array}$ & $\begin{array}{l}\text { Kota Cirebon, Kota Sukabumi } \\
\text { dan Kota Tasikmalaya. }\end{array}$ & $\begin{array}{l}\text { Bogor, Kota Cimahi dan Kota } \\
\text { Depok }\end{array}$ \\
& &
\end{tabular}

Sumber: BPS, data diolah.

Dalam meningkatkan harapan hidup perlu modal dalam memenuhi kebutuhan kesehatan. Kebutuhan kesehatan dapat tercapai apabila memiliki lebih dari 
pendapatan suatu daerah. Variabel pendapatan umumnya diproksikan dengan nilai PDRB atas harga konstan. Berdasarkan rancangan akhir RPJMD Provinsi Jawa Barat periode 2018-2023, laju pertumbuhan PDRB pada tahun 2017 sebesar 5.29\%. Laju pertumbuhan PDRB merupakan laju pendapatan yang diterima oleh daerah di Jawa Barat.

Pada Grafik 3 merupakan nilai pendapatan (PDRB) Kabupaten/Kota dan Provinsi Jawa Barat. Grafik tiga masih banyak daerah di Jawa Barat yang belum mampu mencapai laju PDRB sebesar 5.29\% dan ada beberapa daerah yang sudah mencapai bahkan melebihi angka laju PDRB Provinsi Jawa Barat. Bagi daerah yang masih dibawah pertumbuhan pendapatan sebesar 5.29\%, diindikasikan akan sulit memenuhi kebutuhan kesehatan masyarakat. Laju PDRB yang rendah di Kabupaten/Kota Jawa Barat akan mengalami kesulitan dalam meningkatkan belanja kesehatan dan peningkatan harapan hidup.

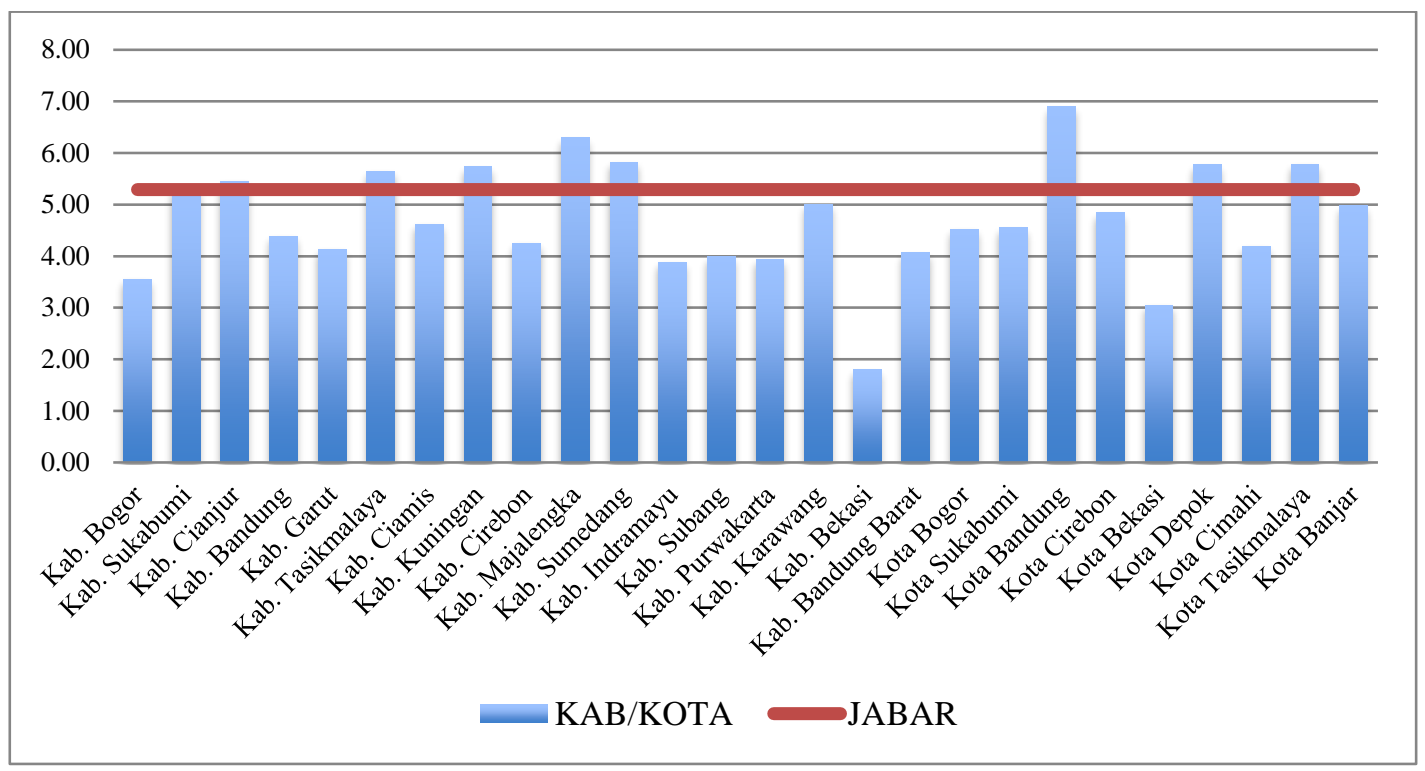

Sumber: BPS, data diolah.

Grafik 3.

Perbandingan PDRB Kabupaten/Kota Provinsi Jawa Barat Tahun 2017 
Dengan adanya desentralisasi fiskal maka setiap daerah diberi kewenangan untuk mengelola keuangannya masing-masing. Hasil dari kewenangan daerah dalam mengelola keuangan yang masih belum mencapai target kesehatan di Jawa Barat. Berbagai upaya harus dilakukan oleh pemerintah daerah untuk mencapai AHH yang ditargetkan oleh Provinsi Jawa Barat. Pengeluaran pemerintah bidang kesehatan menjadi salah satu penentu keberhasilan kesehatan masyarakat yang berkualitas.

Pada Grafik 4, perkembangan rasio pengeluaran kesehatan Kabupaten/Kota di Jawa Barat. Pemerintah daerah Jawa Barat umumnya dalam mengalokasi belanja kesehatan masih jauh dibawah rasio pengeluaran kesehatan Provinsi Jawa Barat. Hanya Kabupaten Bogor dan Kota Bandung memiliki pengeluaran kesehatan diatas Provinsi Jawa Barat. Berdasarkan UU No 36 Tahun 2009, pemerintah mengalokasikan sebesar 5\% dari APBD.

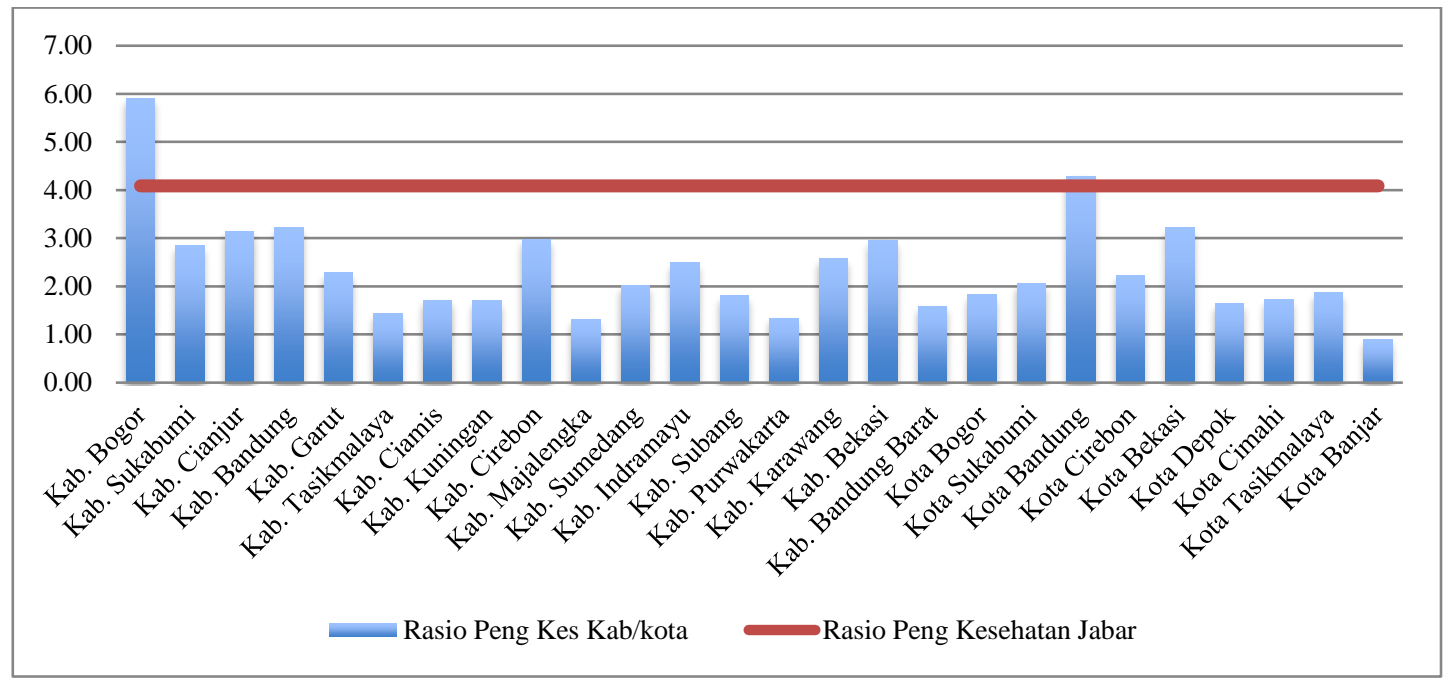

Sumber: BPS, data diolah.

Grafik 4.

Rasio Pengeluaran Kesehatan Kabupaten/Kota terhadap Total Belanja Provinsi Jawa Barat Tahun 2017 
Adhitya Wardhana dan Bayu Kharisma. Angka Harapan Hidup Di Era Desentralisasi.

Dalam Grafik 4 diatas masih banyak pemerintah daerah yang belum memenuhi target alokasi anggaran kesehatan. Dalam meningkatkan AHH dengan alokasi belanja yang rendah akan sangat sulit meningkatkan AHH setiap daerah. Pembangunan kesehatan akan bergerak lambat dalam mencapai kesehatan masyarakat yang berkualitas. Kontribusi pengeluaran pemerintah bidang kesehatan perlu dibarengi dengan kontribusi pengeluaran pemerintah sektor lainnya. Pengeluaran pemerintah yang dapat meningkatkan angka kesehatan seperti pengeluaran pemerintah di bidang infrastruktur seperti akses mendapatkan air bersih. Akses air bersih menjadi salah satu faktor yang dapat mempengaruhi angka harapan hidup. Besarnya akses air bersih diharapkan masyarakat akan lebih sehat. Faktor kesehatan menjadi penentu tingginya harapan hidup.

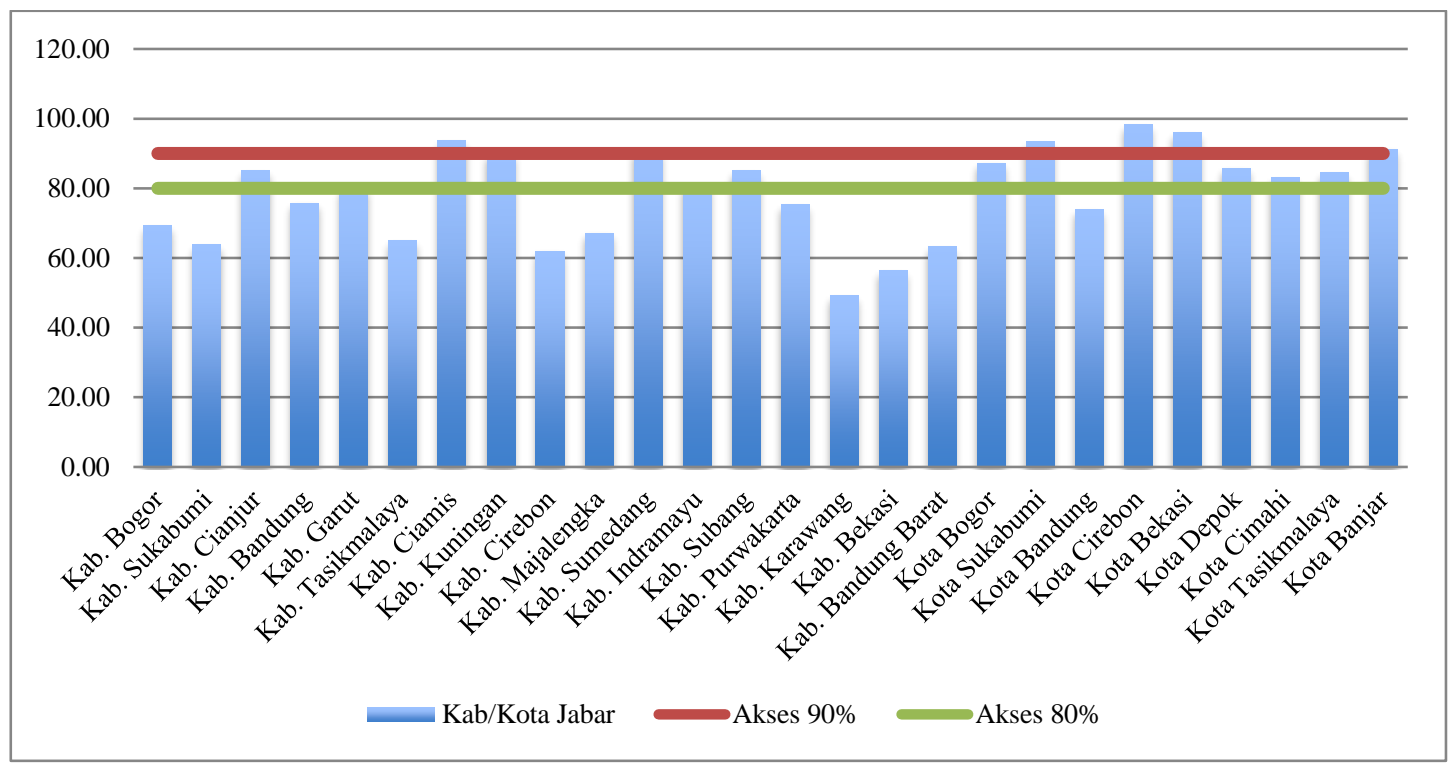

Sumber: BPS, data diolah.

Grafik 5.

Capaian Akses Air Bersih Kabupaten/Kota Provinsi Jawa Barat Tahun 2017 
Pada Grafik 5 diatas memperlihatkan kondisi capaian akses air bersih Kabupaten/Kota di Jawa Barat. Beberapa daerah di Jawa Barat sudah dapat mencapai akses air bersih pada kelompok akses air bersih $80 \%$. Capaian air bersih $80 \%$ terdapat di Kab. Cianjur, Kab. Kuningan, Kota Bogor, Kab. Subang, Kota Depok, Kota Cimahi dan Kota Tasikmalaya. Sedangkan daerah lainnya di Jawa Barat telah mendapatkan akses air bersih dengan capaian 90\%. Beberapa daerah di Jawa Barat masih banyak yang berada dibawah akses air bersih baik di capaian $80 \%$ maupun $90 \%$. Daerah yang masih rendah dalam akses air bersih perlu dukungan pemerintah dalam meningkatkan akses air bersih.

Beberapa penelitian yang menjelaskan keberhasilan pembangunan kesehatan melalui kebijakan desentralisasi. Channa \& Faguet (2016) menyatakan bahwa desentralisasi dapat meningkatkan efisiensi penyediaan kesehatan dan pendidikan di negara-negara berkembang. Wirahadi \& Rosalina (2011) menunjukan bahwa hubungan desentralisasi fiskal berhubungan terbalik dengan kematian bayi di Sumatera Barat. Penelitian ini bertujuan untuk menganalisis determinan yang mempengaruhi angka harapan hidup Kabupaten/Kota di Jawa Barat. Beberapa faktor yang mempengaruhi diantaranya rata-rata lama sekolah, pendapatan (PDRB), akses air bersih dan Kemiskinan (Kabir, 2008). Penelitian ini dapat dimanfaatkan sebagai acuan kebijakan pembangunan kesehatan di Kabupaten/Kota Jawa Barat. Selain itu, penelitian dapat dijadikan rujukan program yang terkait dengan kesehatan maupun peningkatan angka harapan hidup. 


\section{METODE PENELITIAN}

Penelitian ini berupa penelitian deskriptif kuantitatif dengan menggunakan data sekunder. Data sekunder bersumber dari Badan Pusat Statistik, Jawa Barat dalam berbagai edisi dan Dinas Kesehatan Provinsi Jawa Barat. Model penelitian menggunakan model Generalized Least Square (GLS) secara panel data. Periode penelitian ini selama lima tahun (2013-2017). Variabel yang dikaji dalam penelitian ini yaitu angka harapan hidup $(\mathrm{AHH})$ sebagai variabel tidak bebas. Variabel bebas dalam penelitian ini diantaranya : rata-rata lama sekolah (rls), akses air bersih (WATERACC), pendapatan (PDRB) dan kemiskinan (POVERTY). Adapun persamaan ini merupakan modifikasi dari dari penelitian sebelumnya (Kristanto et al., 2019) sebagai berikut.

$\mathrm{AHH}=\mathrm{f}(\mathrm{RLS}, \mathrm{WATERACC}$, PDRB, POVERTY $)$

$\operatorname{LnAHH}_{i t}=\beta_{0}+\beta_{1} \operatorname{LnRLS}_{i t}+\beta_{2} \operatorname{LnWATERACC}_{i t}+\beta_{3} \operatorname{LnPDRB}_{i t}+\beta_{4}$ POVERTY $_{i t}+\mu_{i t}$

Ruang lingkup wilayah penelitian ini yaitu Kabupaten/Kota di Jawa Barat yang memiliki AHH dibawah 71 tahun. Kabupaten/Kota dibawah AHH (71 tahun) diantaranya : Kab. Bogor, Kab. Cianjur, Kab. Garut, Kab. Indramayu, Kab. Majalengka, Kab. Purwakarta, Kab. Sukabumi, Kab. Tasikmalaya dan Kota Banjar. Kemudian penelitian ini akan mengkaji terhadap daerah yang memiliki AHH dibawah 72 tahun. Kabupaten/Kota yang memeliki AHH dibawah 72 tahun : Kab. Bandung Barat, Kabupaten Ciamis, Kab. Cirebon, Kab. Karawang, Kab. Subang, Kab. Sumedang, Kota Cirebon, Kota Sukabumi dan Kota Tasikmalaya. 


\section{HASIL PENELITIAN}

Hasil penelitian terbagi menjadi dua hasil penelitian yaitu $\mathrm{AHH}$ Kabupaten/Kota dibawah 71 tahun dan AHH Kabupaten/Kota dibawah 72 tahun. Secara keseluruhan variabel bebas mempengaruhi signifikan terhadap variabel tidak bebas pada dua persamaan tersebut.

Pada Tabel 2 menunjukkan bahwa hasil intersep pada dua persamaan tanpa dipengaruhi variabel lain maka angka harapan hidup secara rata-rata dapat meningkat sebesar $4.113512 \%$ dan $4.216943 \%$. Varibel bebas yang tidak signfikan pada angka harapan hidup dibawah usia 71 tahun adalah kemiskinan, sedangkan variabel bebas yang tidak mempengaruhi signifikan terhadap variabel tidak bebas pada wilayah angka harapan hidup dibawah usia 72 tahun yaitu variabel akses air bersih dan rata-rata lama sekolah.

Tabel 2.

Hasil Estimasi Persamaan AHH Kabupaten/Kota di Jawa Barat

\begin{tabular}{lcc}
\hline Koefisien & Kab/Kota $<\mathbf{7 1 ~ t h . ~}$ & Kab/Kota $<\mathbf{7 2}$ th. \\
\hline C & 4.113 & 4.217 \\
& $33.57^{* * *}$ & $68.720^{* * *}$ \\
LNWATERACC(-1) & 0.002 & 0.000 \\
& $3.060^{* * *}$ & 1.240 \\
LNRLS & 0.030 & \\
& $2.310^{* *}$ & \\
LNRLS(-1) & & 0.011 \\
& & 0.900 \\
LNPDRB & 0.017 & 0.016 \\
& $3.380^{* * *}$ & $3.210^{* * *}$ \\
LPOVERTY(-1) & -0.009 & -0.011 \\
& -0.960 & $-2.730^{* *}$ \\
\hline R. square (adj) & 0.776 & 0.968 \\
F-statistic & 11.123 & 89.57 \\
Prob(F-statistic) & 0.000 & 0.000 \\
\hline Kerangan: Signifikan
\end{tabular}

Keterangan : Signifikan : $1 \%(* * *), 5 \%(* *), 10 \%(*)$ 
Variabel yang mempengaruhi signifikan terhadap angka harapan hidup di wilayah AHH dibawah usia 71 tahun yaitu akses air bersih, rata-rata lama sekolah dan PDRB. Nilai koefisien dari akses bersih sebesar 0.001526, setiap peningkatan satu persen dari akses air bersih maka akan meningkatkan AHH sebesar $0.001526 \%$ asumsi cateris paribus. Hal ini mengindikasikan bahwa akses air bersih dapat mendorong masyarakat untuk meningkatkan harapan hidupnya. Peningkatan kesehatan dapat melalui hidup bersih. Oleh karena itu, perlunya sarana air bersih untuk meningkatkan kesehatan dan mempertinggi harapan hidup. Menurut Kabir Mahfuz (2008), akses air bersih tidak dapat mempengaruhi langsung terhadap harapan hidup, namun untuk meningkatkan harapan hidup perlu pembangunan kesehatan masyarakat melalui pola hidup sehat (air bersih). Hassan et al., (2016) menunjukkan bahwa peningkatan akses air bersih secara konsisten dapat mempengaruhi angka harapan hidup, apabila akses air bersih tidak diperhatikan oleh pemerintah maka akan memberikan pengaruh yang tidak signifikan terhadap harapan hidup masyarakat. Lin et al. (2012) menyatakan bahwa akses air bersih mempengaruhi positif dan signifikan terhadap angka harapan hidup.

Rata-rata lama sekolah memiliki nilai koefisien sebesar 0.030017, jadi setiap kenaikan satu persen rata-rata lama sekolah akan meningkatkan AHH sebesar 0.030017\% asumsi cateris paribus. Rata-rata lama sekolah merupakan proksi dari variabel pendidikan yang menjelaskan semakin tinggi lama sekolah diharapkan akan lebih memahami penting kesehatan dan harapan hidup masyarakat. Menurut Agho et al., (2011) bahwa peningkatan pendidikan selain untuk kecerdasan masyarakat diharapkan masyarakat dapat memahami informasi kesehatan dan dapat 
berprilaku hidup sehat. Penelitian Hassan et al., (2016) mengidentifikasi bahwa variabel pendidikan mempengaruhi positif dan signifikan terhadap angka harapan hidup. Menurut (Kabir, 2008) bahwa pendidikan dianggap sebagai penentu yang berpengaruh terhadap harapan hidup. Pendidikan memiliki dampak langsung dan tidak langsung pada hasil kesehatan. Pendidikan dapat meningkatkan produktivitas pasar kerja dan pertumbuhan pendapatan, dan mendidik perempuan memiliki efek menguntungkan pada kesehatan anak dan kesejahteraan sosial. Kabir (2008) menyatakan pendidikan juga meningkatkan kesadaran kesehatan orang dalam memperpanjang harapan hidup. Peningkatan pendidikan akan meningkatkan produktivitas wanita di rumah sehingga dapat meningkatkan kesehatan keluarga dan kelangsungan hidup anak.

Terakhir, nilai koefisien dari pendapatan (PDRB) sebesar 0.016556. Artinya, kenaikan satu persen dari PDRB akan meningkatkan AHH sebesar $0.016556 \%$ asumsi cateris paribus. Menurut Kabir Mahfuz (2008), peningkatan harapan hidup yang absolut didukung oleh peningkatan pendapatan, ketika pendapatan terus meningkatkan maka tidak lagi dihubungkan dengan harapan hidup. Penelitian Roger dalam Kabir Mahfuz (2008), menjelaskan harapan hidup akan meningkat ketika pendapatan masyarakat mengalami peningkatan. Tingginya pendapatan masyarakat akan memenuhi kesehatan melalui belanja kesehatan. Hal ini sesuai dengan penelitian Hassan et al., (2016) bahwa pendapatan memilki korelasi positif dengan harapan hidup.

Selanjutnya, variabel yang mempengaruhi angka harapan hidup pada kelompok daerah AHH dibawah 72 tahun yaitu pendapatan (PDRB) dan 
pengangguran. Nilai koefisien PDRB sebesar 0.015752, setiap kenaikan satu persen dari variabel pendapatan (PDRB) akan meningkatkan angka harapan hidup sebesar $0.015752 \%$. Pendapatan yang tinggi akan lebih mudah dalam mengkonsumsi barang kesehatan sehingga diharapakan dapat meningkatkan $\mathrm{AHH}$. Menurut Anand \& Ravallion (1993) bahwa dampak pendapatan nasional akan meningkatkan pengeluaran public khususnya kesehatan sehingga akan mengangkat pertumbuhan AHH.

Kesehatan suatu populasi sangat berkaitan langsung dengan pendapatan ratarata, pendapatan rata-rata yang tinggi akan berkorelasi positif dengan harapan hidup. Pendapatan suatu wilayah menjadi kunci kualitas hidup yang dilihat dari besaran pendapatan masyarakat tersebut. Anand \& Ravallion (1993) menunjukan bahwa penduduk negara-negara kaya dengan pendapatan dan pengeluaran kesehatan yang tinggi akan memiliki kualitas hidup yang lebih tinggi daripada penduduk negara-negara miskin. Adanya korelasi positif yang kuat antara harapan hidup dan pendapatan di negara maju, pendapatan harus menjadi penentu permintaan kesehatan di negara-negara berkembang.

Variabel kemiskinan tahun sebelumnya mempengaruhi negatif dan signifikan terhadap angka harapan hidup. Nilai koefisien dari variabel sebesar 0.011246, peningkatan kemiskinan tahun sebelumnya akan mengurangi angka harapan hidup sebesar $0.011246 \%$ asumsi cateris paribus. Bagi masyarakat yang hidup dibawah garis kemiskinan akan mengalami kesulitan untuk meningkatkan angka harapan hidup. Begitu juga dalam sisi konsumsi di bidang kesehatan yang tidak dapat terpenuhi apabila sebagian besar penduduk dibawah garis kemiskinan. Menurut 
Tafran et al., (2020), perlunya mengukur pendapatan minimum suatu rumah tangga untuk memenuhi kebutuhan dasar makanan dan non makanan, adanya populasi yang pendapatannya kurang dari batasan minimum akan kesulitan untuk mendapatkan standar kesehatan maupun harapan hidup.

Kristanto et al., (2019) menjelaskan peningkatan beban ketergantungan dan kemiskinan dan menurunkan angka harapan hidup. Peningkatan pendapatan masyarakat menjadi salah satu bagian dalam mengurangi angka kemiskinan sehingga dapat meningkatkan angka harapan hidup. Perbedaan terbesar antara kemiskinan dengan harapan hidup rata-rata akan terjadi antara usia tidak produktif. Perlunya memaksimalkan usia produktif untuk mengurangi angka kemiskinan sehingga harapan hidup di suatu wilayah dapat meningkat. Menurut Albala et al., (2002) hasil temuannya adanya korelasi antara kemiskinan dengan angka mortalitas yang berhubungan positif. Besarnya angka mortalitas mencerminkan ketidaksanggupan suatu wilayah mencapai target angka harapan hidup.

Berdasarkan klasifikasi AHH Kabupaten/Kota di Jawa Barat, hanya variabel akses air bersih, rata-rata lama sekolah dan pendapatan (PDRB) yang dapat mempengaruhi AHH Kabupaten/Kota dibawah usia 71 tahun. Dalam meningkatkan $\mathrm{AHH}$ harus ditunjang dengan akses air bersih dan peningkatan pendidikan dan peningkatan pendapatan. Daerah yang memiliki AHH yang berada dibawah usia 71 tahun, pemerintah daerah perlu meningkatkan pendapatan dan pendidikan agar target $\mathrm{AHH}$ tercapai. Hal ini terlihat dari nilai ketiga variabel tersebut tidak terlalu besar mempengaruhi angka harapan hidup. 
Sementara itu, variabel bebas yang mempengaruhi AHH di Kabupaten/Kota dibawah usia 72 tahun yaitu variabel pendapatan dan kemiskinan. Peningkatan pendapatan menjadi kunci penting untuk meningkatkan pengeluaran kesehatan sehingga target angka harapan hidup usia 72 tahun tercapai. Kemudian variabel kemiskinan menjadi hal yang harus diperhatikan agar tidak terjadi penurunan pengeluaran kesehatan. Kemiskinan dapat terjadi pada daerah yang memiliki pendapatan tinggi akibat tingginya daya saing, sehingga akan terjadi ketimpangan dari sisi pengeluaran kesehatan. Dari kedua klasifikasi wilayah beradasarkan angka harapan hidup (AHH), faktor pendapatan (PDRB) di daerah Jawa Barat merupakan faktor utama untuk meningkatkan angka harapan hidup. Besarnya pendapatan masyarakat maka masyarakat akan lebih berkesempatan meningkatkan pengeluaran kesehatan.

\section{SIMPULAN DAN SARAN}

Hasil penelitian mendapatkan hasil variabel akses air bersih, rata-rata lama sekolah dan pendapatan (PDRB) mempengaruhi signifikan terhadap angka harapan hidup pada usia dibawah usia 71 tahun. Kemudian variabel yang mempengaruhi signifikan pada AHH dibawah usia 72 tahun yaitu variabel pendapatan (PDRB) dan kemiskinan. Variabel pendapatan (PDRB) menjadi variabel yang mempengaruhi AHH dibawah usia 71 dan 72 tahun.

Variabel pendapatan (PDRB) dalam penelitian ini menjadi variabel penentu peningkatan angka harapan hidup di Kabupaten/Kota Jawa Barat. Peningkatan ratarata lama sekolah menjadi kunci kecerdasan masyarakat dalam memahami 
pentingnya kesehatan. Selanjutnya, semakin baik tingkat pendidikan diharapkan semakin memahami manfaat kesehatan. Manfaat kesehatan diharapkan dapat meningkatkan angka harapan hidup di Kabupaten/Kota Jawa Barat. Pemerintah perlu meningkatkan sarana air bersih sebagai bentuk peningkatan infrastruktur di bidang kesehatan, dimana pengembangan sarana air bersih dapat meningkatkan angka kesehatan dan angka harapan hidup. Selain itu, kemiskinan yang terdapat di daerah berpendapatan tinggi maupun rendah, perlu pengawasan pemerintah daerah dalam melihat pertumbuhan kemiskinan, dimana semakin besar kemiskinan maka semakin mempersempit masyarakat untuk mengeluarkan kebutuhan kesehatan. Pengeluaran kesehatan sebagai upaya masyarakat dalam mencapai harapan hidup yang tinggi.

\section{REFERENSI}

Agho, K. E., Dibley, M. J., Odiase, J. I., \& Ogbonmwan, S. M. (2011). Determinants of exclusive breastfeeding in Nigeria. BMC Pregnancy and Childbirth. https://doi.org/10.1186/1471-2393-11-2

Albala, C., Vio, F., Kain, J., \& Uauy, R. (2002). Nutrition transition in Chile: determinants and consequences. Public Health Nutrition. https://doi.org/10.1079/phn2001283

Anand, S., \& Ravallion, M. (1993). Human Development in Poor Countries: On the Role of Private Incomes and Public Services. Journal of Economic Perspectives. https://doi.org/10.1257/jep.7.1.133

Channa, A., \& Faguet, J. P. (2016). Decentralization of health and education in developing countries: A quality-adjusted review of the empirical literature. World Bank Research Observer. https://doi.org/10.1093/wbro/lkw001

Hassan, F. A., Minato, N., Ishida, S., \& Mohamed Nor, N. (2016). Social Environment Determinants of Life Expectancy in Developing Countries: A Panel Data Analysis. Global Journal of Health Science. https://doi.org/10.5539/gjhs.v9n5p105 
Kabir, M. (2008). Determinants of Life Expectancy in Developing Countries. The Journal of Developing Areas. https://doi.org/10.1353/jda.2008.0013

Khan, R. E. A., \& Raza, M. A. (2016). Determinants of malnutrition in Indian children: new evidence from IDHS through CIAF. Quality and Quantity. https://doi.org/10.1007/s11135-014-0149-x

Kristanto, E., Daerobi, A., \& Samudro, B. R. (2019). Indonesian Life Expectancy: Role of Health Infrastructure and Socio-Economic Status. Signifikan: Jurnal Ilmu Ekonomi. https://doi.org/10.15408/sjie.v8i1.9579

Lin, R. T., Chen, Y. M., Chien, L. C., \& Chan, C. C. (2012). Political and social determinants of life expectancy in less developed countries: A longitudinal study. BMC Public Health. https://doi.org/10.1186/1471-2458-12-85

Tafran, K., Tumin, M., \& Osman, A. F. (2020). Poverty, income, and unemployment as determinants of life expectancy: Empirical evidence from panel data of thirteen Malaysian States. Iranian Journal of Public Health.

Wirahadi, A., \& Rosalina, E. (2011). Analisa pengaruh kebijakan desentralisasi fiskal terhadap outcomes bidang kesehatan di kabupaten/kota propinsi Sumatera Barat. Akuntansi \& Manajemen. 